\title{
Pendampingan Terhadap Siswa Melalui Kelas Inspirasi di SDN 7 Jeumpa Kabupaten Aceh Barat Daya
}

\author{
${ }^{1}$ Anhar Fazri, ${ }^{2}$ Al Munawir, ${ }^{3}$ Putri Kemala Sari, ${ }^{4}$ Sri Wahyu Handayani, \\ ${ }^{5}$ Zuhrizal Fadhly, ${ }^{6}$ Alimas Jonsa, \\ 1Jurusan Ilmu Komunikasi, Universitas Teuku Umar \\ Email: anhar.fazri@utu.ac.id \\ 2Jurusan Teknik Mesin, Universitas Teuku Umar \\ Email : almunawir@utu.ac.id \\ 3Jurusan Ilmu Hukum, Universitas Teuku Umar \\ Email : putrikemalasari@utu.ac.id \\ 456Jurusan Ilmu Administrasi Negara, Universitas Teuku Umar \\ Email : sriwahyuhandayani@utu.ac.id \\ Email: zuhrizalfadhly@utu.ac.id \\ Email : alimasjonsa@gmail.com
}

\begin{abstract}
Education is an effort to channel knowledge from educators to students through a tiered process. Elementary school students are students at the next level who must obtain extraordinary motivation to support the dream process they have, especially for students at SDN 7 Jeumpa, Aceh Barat Daya District. That way, creating an inspiring class that can give an idea of their dreams in the future will be a form of motivation that is able to push them toward a better future. The method used in this service is by lecturing, sharing sessions, and direct practice in accordance with the profession. The results of the dedication show that very many students at SDN 7 Jeumpa, Southwest Aceh District do not have high motivation in achieving their dreams and also that some of these students are still hesitant in determining their dreams, so they only follow what is conveyed by other students. That way, the results of this service provide a clear picture of the dream they will achieve and good motivation for students to pursue that dream.
\end{abstract}

Keyword : Education, Communication, Motivation, Inspiration, and SDN 7

\begin{abstract}
Abstrak
Pendidikan menjadi upaya penyaluran ilmu pengetahuan dari pendidik kepada peserta didik melalui proses berjenjang. Pelajar tingkat sekolah dasar merupakan peserta didik ditingkat selanjutnya yang harus memperoleh motivasi yang luar biasa untuk menunjang proses impian yang mereka miliki, khususnya bagi pelajar di SDN 7 Jeumpa Kabupaten Aceh Barat Daya. Dengan begitu, membuat kelas inspirasi yang bisa memberikan gambaran tentang impian mereka dimasa mendatang akan menjadi sebuah bentuk motivasi yang mampu mendorong mereka ke arah masa depan yang lebih baik. Metode yang digunakan dalam kegiatan pengabdian ini yaitu dengan cara ceramah, sharing session, dan praktek langsung sesuai dengan profesi yang dimiliki. Hasil pengabdian menunjukkan bahwa sangat banyak dar pelajar tingkat SDN 7 Jeumpa Kabupaten Aceh Barat Daya belum mempunyai motivasi yang tinggi dalam meraih impian yang mereka miliki dan juga pada sebagian pelajar tersebut masih bimbang dalam menentukan impian mereka, sehingga mereka hanya mengikuti apa yang disampaikan oleh pelajar lainnya. Dengan begitu, hasil dari pengabdian ini memberikan gambaran yang jelas tentang impian yang akan mereka raih dan motivasi yang baik bagi pelajar untuk mengejar impian tersebut.
\end{abstract}

Kata kunci : Pendidikan, Komunikasi, Motivasi, Inspirasi, dan SDN 7 


\section{PENDAHULUAN}

Pendidikan merupakan upaya dalam memberikan peserta didik berbagai ilmu pengetahuan dan pengalaman oleh tenaga pendidik. Kegiatan pendidikan ini akan dilakukan secara terus menerus baik itu dalam konteks pendidikan formal maupun non formal. Pendidikan yang berjenjang akan terus memberikan peningkatan ilmu pengetahuan bagi peserta didik. Namun, tentunya tingkat motivasi juga akan memberikan dorongan yang luar biasa bagi peserta didik dalam menentukan cita-citanya di masa mendatang.

Kelas Inspirasi adalah gerakan para profesional turun ke Sekolah Dasar (SD) selama sehari, berbagi cerita dan pengalaman kerja juga motivasi meraih cita-cita. Tujuan dari Kelas Inspirasi ini ada dua, yaitu menjadi wahana bagi sekolah dan siswa untuk belajar dari para profesional, serta agar para profesional, khususnya kelas menengah secara lebih luas, dapat belajar mengenai kenyataan dan fakta mengenai kondisi pendidikan kita. (Kelasinspirasiyogyakarta, n.d.)

Kondisi saat ini, memberikan banyak gambaran tentang bagaimana pelajar tingkat sekolah dasar belum memiliki motivasi yang baik dalam meraih impiannya dan tentunya mereka masih bingung terhadap citacita yang dimiliki. Sehingga yang terjadi adalah mereka menyampaikan dan sekaligus mengikuti impian dan cita-cita yang dimiliki oleh kawankawan atau generasi sebelum mereka.

Guru adalah orang yang secara sadar mengarahkan pengalaman dan tingkah laku dari seorang individu sehingga dapat terjadi pendidikan. (Uno, 2007)

Dalam sistem pendidikan, Negara yang maju dapat dipastikan memiliki sistem dan kualitas pendidikan yang sangat baik. Pada tahapan ini negara maju sudah memiliki konsep dalam mengembangkan profesi dan potensi yang dimiliki oleh anak-anak sekolah dasar. Namun, dalam usaha mencerdaskan bangsa, pemerintah mendirikan sekolah-sekolah dari mulai tingkat dasar sampai pendidikan tingkat tinggi. Sekolah Dasar adalah jenjang paling dasar pendidikan formal di Indonesia. Sekolah Dasar ditempuh dalam waktu 6 tahun, dimulai dari kelas 1 sampai kelas 6. Dengan penerapan sistem berjenjang tersebut dapat memberikan dan meningkatkan potensi yang dimiliki oleh peserta didik.

Menurut Hurlock, masa anak adalah periode krisis yang ditandai dengan suatu periode dimana anak membentuk kebiasaan untuk mencapai sukses. Pada masa anak atau usia sekolah dasar, anak mulai berusaha untuk menyesuaikan diri dengan orang dewasa dan mulai mempelajari keterampilan dan kompetensi tertentu. (Hurlock, 1994) 
Pengenalan profesi kepada anakanak merupakan sebuah hal yang sangat penting. Hal ini, nantinya akan berkaitan dengan cita-cita dan impian yang dimiliki oleh anak-anak tingkat sekolah dasar. Dengan pengenalan profesi sedini mungkin akan memberikan anak modal hidup bagi mereka dan tentunya anak-anak akan menghargai profesi tersebut dengan belajar bagaimana meraih impian mereka terhadap profesi yang ada. Berdasarkan status pekerjaan, dilihat berdasarkan tren lapangan pekerjaan selama Agustus 2018-Agustus 2019, lapangan pekerjaan yang mengalami peningkatan persentase penduduk yang bekerja terutama pada Perdagangan besar dan eceran $(1,56$ persen poin), Jasa Pendidikan (0,85 persen poin), dan Administrasi Pemerintahan (0,83 persen poin). Sementara lapangan pekerjaan yang mengalami penurunan utamanya pada Pertanian (2,80 persen poin); Konstruksi (1,12 persen poin); serta Jasa Keuangan dan Asuransi (0,12 persen poin).

Pada dasarnya kita mengetahui bahwa semua manusia mempunyai cita-cita. Dengan cita-cita tersebut, nantinya akan mempengaruhi semua proses kehidupan manusia tersebut baik dari sisi minat, motivasi dan prestasi yang akan mereka raih dikemudian hari. Dalam hal ini, citacita dapat juga diartikan sebagai tujun hidup seseorang dimasa depan. Citacita merupakan sebuah keinginan yang ditetapkan oleh seseorang dan menjadi bagian dalam unsur hidupnya untuk bisa dicapai dan menjadi prestasi tertinggi dimasa depan.

Pada daerah tertentu pemahaman terhadap profesi dan cita-cita masih sangat kurang, dan bahkan terkadang sebagian orang tua terlihat membatasi ruang impian yang dimiliki oleh anakanak mereka. Pada tahapan ini, banyak orang tua berpendapat untuk menjadi orang sukses hanya perlu sekolah setinggi mungkin dan membutuhkan pengeluaran yang tinggi. Padahal pada kenyataannya banyak program-program yang menawarkan beasiswa dan programprogram gratis untuk meningkatkan pemahaman siswa terhadap impiannya.

Pendidikan di sekolah dasar bertujuan membekali peserta didik dengan kemampuan dasar untuk mengembangkan kehidupannya sebagai pribadi, anggota masyarakat, warga negara, serta untuk mempersiapkan diri mengikuti pendidikan menengah (UUSPN No. 20 Tahun 2003). Pada tahapan pelaksanaan pendidikan pada tingkatan pendidikan di sekolah dasar, proses pembelajaraan dengan kompetensi yang harus dikuasai oleh anak sekolah dasar sebagai peserta didik bukan hanya dengan berupa proses penyaluran ilmu pengetahuan seperti keterampilan dasar membaca, menulis, dan berhitung. Akan tetapi, terdapat pula beberapa kompetensi yang harus disampaikan kepada para siswa baik itu dalam bidang sosial, 
pribadi, dan karir yang tentunya perlu dikembangkan oleh peserta didik di sekolah dasar. Dalam hal pemahaman mengenai karir dan cita-cita dimasa depan, peserta didik diarahkan agar mampu memahami dirinya sendiri, memahami dunia kerja, serta memiliki kesadaran akan pentingnya kerelaan untuk bekerjasama dan bertindak dengan penuh tanggung jawab. Pengenalan dan penanaman kesadaran ini dilakukan secara bertahap dari hal yang sederhana ke hal yang lebih kompleks untuk menjadikan tetap fokus pada impian terhadap profesi yang mereka citacitakan.

\section{METODE PELAKSANAAN}

Penggunaan metode yang digunakan dalam pengabdian ini adalah menyesuaikan dengan kondisi pada waktu di dalam kelas diantaranya yaitu, dengan cara ceramah, sharing session, dan praktek langsung sesuai dengan profesi yang dimiliki. Seluruh metode yang digunakan dalam pengabdian ini bertujuan untuk memberikan gambaran dan motivasi bagi pelajar tingkat sekolah dasar di SDN 7 Jeumpa Kabupaten Aceh Barat Daya. Tujuan akhirnya adalah agar materi yang disampaikan dapat dipahami dengan baik oleh para siswa.

Namun, sebelum kegiatan para peserta terlebih dahulu diberikan permainan untuk menambah suasana yang menyenangkan dalam memotivasi mereka dan setelah kegiatan dilakukan pembuatan pohon cita-cita yang nantinya akan dimuat cita-cita dari peserta tersebut.

\section{HASIL DAN PEMBAHASAN}

Kecamatan

Jeumpa merupakan salah satu kecamatan yang ada di Kabupaten Aceh Barat Daya. Kecamatan ini juga memiliki beberapa sekolah Tingkat SD sederajat sama dengan kecamatan lainnya. Letak kecamatan ini sangat berdekatan dengan kecamatan Blang Pidie yang merupakan ibu kota dari kabupaten Abdya. Terdapat sekitar sekolah dasar di kecamatan tersebut, yaitu:

Tabel 1. Daftar Sekolah Dasar Di Kecamatan Jeumpa

Kabupaten Aceh Barat Daya

\begin{tabular}{cll}
\hline No & \multicolumn{1}{c}{ Nama Sekolah } & \multicolumn{1}{c}{ Alamat } \\
\hline 1 & SDN 1 Jeumpa & Alue Sungai Pinang \\
\hline 2 & SDN 2 Jeumpa & Alue Sungai Pinang \\
\hline 3 & SDN 3 Jeumpa & Cot Mane \\
\hline 4 & SDN 4 Jeumpa & Alue Rambot \\
\hline 5 & SDN 5 Jeumpa & Ladang Neubok \\
\hline 6 & SDN 6 Jeumpa & Iku Lhung \\
\hline 7 & SDN 7 Jeumpa & Kuta Makmur \\
\hline
\end{tabular}




8 SDN 8 Jeumpa Padang Geulumpang

Sumber : Dinas Pendidikan Kabupaten Aceh Barat Daya, 2019

Hasil yang dicapai dalam program pengabdian yang telah penulis lakukan di SDN 7 Jeumpa Kabupaten Aceh Barat Daya ini memperlihatkan bahwa para pelajar ini memiliki citacita yang sangat tinggi dan mereka mempunyai semangat yang tinggi untuk meraihnya. Dalam hal ini membuktikan pada satu sisi kondisi daerah akan menentukan sejauh mana semangat yang dimiliki oleh para remaja tingkat sekolah dasar ini tidak takut lagi untuk memiliki cita-cita tinggi dan bersedia berusaha untuk meraihnya. Pada program pelaksanaan pengabdian ini terutama pada siswa/i menerima dengan baik motivasi dan inspirasi yang diberikan oleh para pemateri dan mereka mendengarkan secara serius sehingga memberikan suasana yang lebih menyenangkan.

Pada penerapan pengabdian dengan program kelas inspirasi ini, bukan hanya anak-anak sekolah dasar yang termotivasi dan bahkan guru kelas juga semakin sadar dalam bagaimana mengembangkan bakat minat yang dimiliki oleh para siswa sekolah dasar tersebut. Dari kegiatan tersbut juga, memberikan banyak pengertian kepada orang tua tentang cita-cita tinggi yang dimiliki dan tidak seharunya ada pembatasan terhadap impian yang ingin diraih oleh anakanak.
Menurut Usman tugas guru sebagai profesi meliputi mendidik, mengajar, dan melatih. Mendidik berarti meneruskan dan mengembangkan nilai-nilai hidup. Mengajar berarti meneruskan dan mengembangkan ilmu pengetahuan dan teknologi. Melatih artinya mengembangkan keterampilanketerampilan pada siswa. Tugas guru dalam bidang kemanusiaan di sekolah harus dapat menjadikan dirinya sebagai orang tua kedua. Guru harus mampu menarik simpati sehingga guru menjadi idola para siswanya. Pelajaran apapun yang diberikan, hendaknya dapat menjadi motivasi bagi siswanya dalam belajar. Masyarakat menempatkan guru pada tempat yang lebih terhormat di lingkungannya, karena seorang guru di depan memberikan suri tauladan pada siswa ataupun masyarakat secara umum, di tengah-tengah membangun dan menggerakkan siswa atau warganya, dan di belakang memberikan dorongan dan motivasi untuk maju dan bangkit membangun kehidupan yang lebih baik, ini sesuai dengan ungkapan "Ing ngarso sung tulodho, Ing madyo mangun karso, Tut wuri handayani". Artinya bahwa guru di depan memberikan contoh pada siswanya, di tengah menggerakkan siswa dan di belakang memberikan dorongan untuk maju.(Usman, 1995) 
Siswa/i SDN 7 Jeumpa Kabupaten Aceh Barat Daya ini menanggapi dengan antusias dan juga memberikan gambaran suasana yang lebih bergairah dan kondusif ketika mereka mendengarkan motivasi dan inpirasi yang mereka lihat dan dengarkan langsung dari para pemateri. Berikut ini suasana kegiatan saat pemateri sedang memberikan dan berdiskusi dengan para siswa.

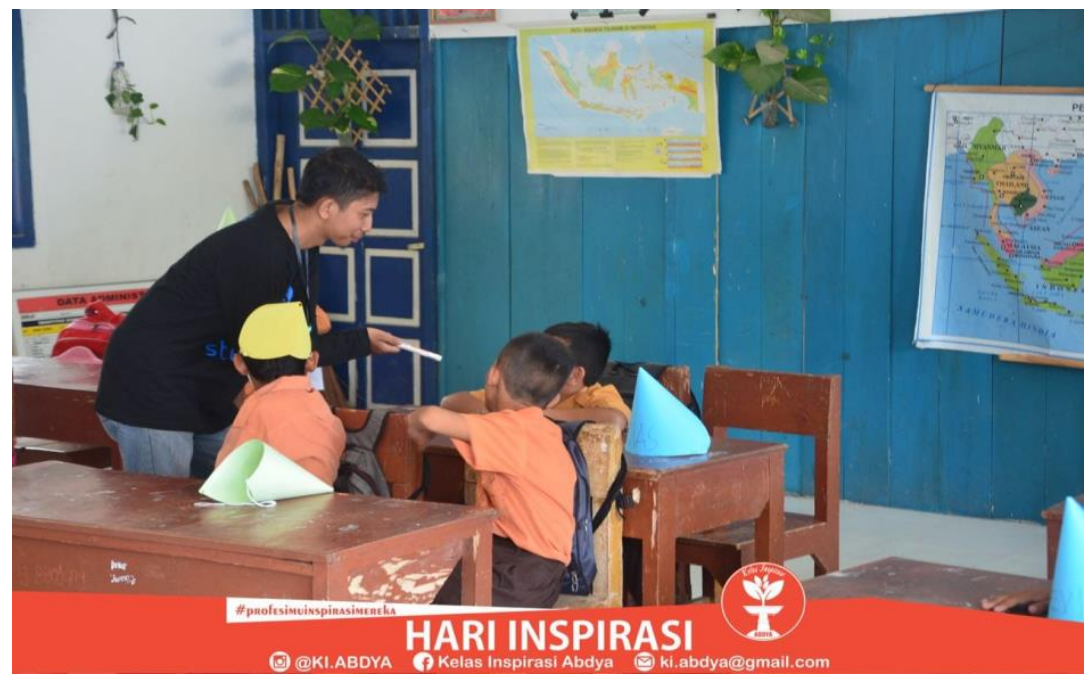

Gambar 1. Pemateri sedang Berdiskusi dengan Para Siswa

Program-program dilaksanakan pada kegiatan kelas inspirasi ini memberikan berbagai pengetahuan yang berbeda bagi para pelajar sekolah tersebut. Dengan berbagai profesi yang dimiliki oleh para pemateri di kelas inspirasi dapat memberikan berbagai ragam cita-cita yang lebih berwarna bagi mereka di masa mendatang. Namun, tetap saja tanggapan akan selalu berbeda pada setiap kalangan siswa-i tersebut.

Program pengabdian melalui kelas inspirasi ini di dasarkan kepada psikologi siswa dan psikologi positif, yang mana para siswa diminta untuk dapat menggali hal-hal positif yang ada dalam dirinya. Program ini memberikan gambaran pada penulis untuk mengeahui bahwa tidak semua siswa memiliki cita-cita dan impian yang sama dalam meraih impian yang mereka miliki dengan berbagai alasan berbeda. Dan tentunya hal tersebut memberikan dampak bagi pemateri dalam mempersiapkan materi dan model penyampaian agar lebih mudah diterima oleh para siswa/i tersebut.

Konsep pendidikan yang baik juga harus disertai dengan model komunikasi yang dapat menjadi penyimbang dan membawa pengaruh lebih pada saat proses pendidikan dilaksanakan. Karna pada saat ini, pendidikan yang baik tidak akan memberikan efek bagi siswa/i apabila tidak dibarengi dengan tata cara berkomunikasi yang benar. 
Pada dasarnya, komunikasi merupakan proses yang dilakukan oleh satu orang atau lebih. Dan pada konsepnya, komunikasi akan berlangsung efektif dengan menggunakan model yang tepat.

Hal ini sesuai dengan konsep pendidikan yang dikemukakan oleh Ki Hajar Dewantara yaitu: ing ngarso sung tulodho, ig madya mangun karso, tut wuri handayani, yang artinya: di depan memeberi contoh atau teladan yang baik, di tengah membangun kehendak/ kemauan (inisiatif), di belakang memberi dorongan/ semangat. (Yusuf, 1990)

Dalam proses pendidikan tentunya pengembangan model komunikasi dan teknologi pendidikan sangat diperlukan. Dalam hal ini ada satu model komunikasi yang sangat sederhana namun sangat memberikan manfaat dalam bidang pengembangan pendidikan yaitu model SMCR (source, message, channel, receiver) yang artinya (sumber, pesan, saluran, penerima). Penggunaan model ini akan menunjukkan pada penerapan dua konsep, yaitu (1) proses yang akan berhubungan dengan keseluruhan penyampaian pesan dari sumber kepada penerima, dan (2) tahapan selanjutnya yaitu akan menunjukkan adanya unsur-unsur yang terlibat di dalam proses yang terjadi tersebut.

Dalam model SMRC ini, pada prosesnya yaitu Murid (penerima) dan guru atau bahan (sumber) adalah bagian internal teknologi pendidikan, yang dipandang sebagai bagian unsur- unsur komunikasi yang paling penting. Dengan begitu, mereka menjadi bagian dari proses komunikasi itu sendiri dan juga akan menjadi proses yang tidak keluar dari perkembangan teknologi pendidikan.

Metode komunikasi yang digunakan dalam penyampaian pesan yang dilakukan di Kelas Inspirasi Kabupaten Aceh Barat Daya adalah bersifat edukatif mengingat khalayak pada kegiatan tersebut adalah murid Sekolah Dasar yang bertujuan agar setelah kegiatan berlangsungnya kelas inspirasi dapat meningkatkan pemahaman siswa untuk lebih terbuka tentang berbagai profesi yang ada dalam meraih impian mereka.

Pesan edukasi yang diberikan dalam kegiatan kelas inpirasi tersebut adalah dengan menyampaikan pesan siapakah aku, apakah profesiku apa yang dilakukan profesiku di masyarakat? Dan bagaimana cara menjadi aku?. Dengan cara seperti itu, diharapkan bahwa penyampaian pesan dapat menjadi menjadi sukses jangan pernah berhenti belajar, jangan malas, harus menuruti apa kata orang tua, dan berdoa dengan usaha yang giat.

Komunikasi dalam pendidikan merupakan komunikasi ataupun interaksi yang terjadi di dalam dunia pendidikan, bahkan ia sangatbesar peranannya dalam menentukan keberhasilan pendidikan yang bersangkutan.

Dalam prosesnya keberadaan komunikasi juga merupakan hal yang 
sangat penting dalam setiap interaksi baik itu individu maupun kelompok. Komunikasi tersebut sangat dibutuhkan untuk memberikan pengertian dan saling memahami dalam setiap interaksi yang akan dijalani oleh individu dan kelompok begitu juga bagi kalangan siswa/i SDN 7 Jeumpa Kabupaten Aceh Barat. Dan proses komunikasi dapat dikatakan berhasil apabila apabila hubungan komunikasi internalnya hamonis.

Strategi dalam penyampaian pesan pada program kegiatan kelas inspirasi dengan menggunakan model komunikasi persuasif. Komunikasi persuasif yang dipakai bertujuan agar murid dapat tersuggesti dengan berbagai profesi yang disampaikan oleh para pemateri. Sehingga nantinya akan menimbulkan semangat dan termotivasi dalam belajar untuk meraih cita-cita dan impian yang mereka miliki.

Pada program kelas inspirasi ini, untuk kegiatan membangkitkan minat dan perhatian bukanlah hal yang mudah untuk dilakukan pada khalayak, apalagi bagi anak tingkat sekolah dasar. Proses komunikasi dengan penyusunan pesan yang baik akan menciptakan tingkat komunikasi yang sukses. Pada tahapan ini seorang komunikator harus dapat mengembangkan kreatifitas dari setiap pesan yang disampaikannya.

Dalam setiap kegiatan dan program pasta ada kendala yang akan dihadapi begitu juga pada kelas inspirasi ini. Pada kegiatan kelas inspirasi terdapat beberapa kendala yang terjadi, dan seringkali kendala tersebut hadir dari diri pribadi dan kelompok lingkungan terdekat, baik itu dari kurangnya kesiapan dan takut akan masa depan yang akan dihadapinya. Pada prosesnya, perbedaan daerah turut mempengaruhi terhadap impian yang dimiliki.

Berdasarkan segi pelaksanaanya, Kelas Inspirasi melalui para pemateri melakukan penyampaian pesan dengan metode yang telah disiapkan masih dengan bentuk dan proses yang komunikatif. Dan dalam artian komunikator menyediakan saluransaluran tertentu untuk menguasai motif-motif yang ada pada diri khalayak. Atau ia memulai komunikasi di mana khalayak itu berada (start where the audience) kemudian diubah sedikit menjadi demi sedikit ke arah tujuan komunikator.

Berikut dibawah ini adalah suasana pasca kegiatan berakhir, siswa, guru dan para pemateri mengabadikan momen dengan foto bersama. 


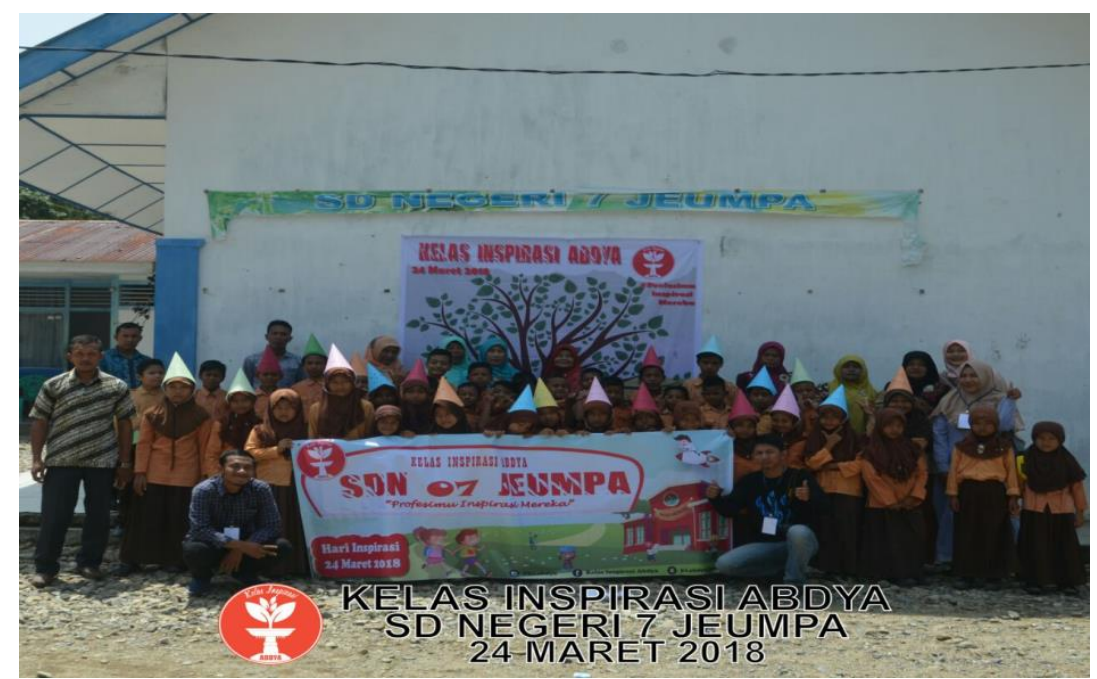

Gambar 1. Pemateri, Guru dan Siswa Foto Bersama Pasca Kegiatan

\section{PENUTUP}

Pendidikan merupakan unsur terpenting dalam menunjang kehidupan manusia untuk menjadi lebih baik pada setiap periodenya. Akan tetapi, untuk memperoleh hasil yang terbaik dari setiap tingkatan pendidikan tentunya para pelajar harus mempunyai motivasi yang memberikan inspirasi agar mereka untuk mengejar keinginannya. Namun, pelajar di tingkat sekolah dasar akan memiliki kondisi dan motivasi yang sangat berbeda.

Begitu juga yang terjadi di SDN 7 Jeumpa Kabupaten Aceh Barat Daya yang memiliki perbedaan motivasi dengan daerah lainnya, dan tentunya juga memperoleh inspirasi yang tidak sama. Hal tersebut akan mempengaruhi cita-cita yang ingin mereka capai pada masa mendatang.

Pada program pengabdian ini memberikan gambaran, motivasi dan inspirasi yang jelas bagi siswa/i SDN 7 Jeumpa Kabupaten Aceh Barat Daya agar mereka menggapai apapun impiannya dan tentu banyak jalan untuk meraihnya.

\section{DAFTAR PUSTAKA}

Hurlock, E. (1994). Psikologi Perkembangan, Suatu Pendekatan Sepanjang Rentang Kehidupan. Erlangga.

Kelasinspirasiyogyakarta. (n.d.). Tentang Kelas Inspirasi. Retrieved October 15, 2019, from https://kelasinspirasiyogyakarta. org/tentang-ki/

Uno, H. . (2007). Profesi Kependidikan: problema, solusi, dan reformasi pendidikan di indonesia (1st ed.). Bumi Aksara.

Usman, M. U. (1995). Menjadi Guru Profesional. Remaja Rosdakarya.

Yusuf, P. M. (1990). Komunikasi Pendidikan dan Intruksional. Remaja Rosdakarya. 